\title{
Moscow-Rome-Havana: A Film-Theory Road Map
}

\section{MASHA SALAZKINA}

All groups of kino-observers will be drawn into the production of future kino-eye series. They will be the author-creators of all subsequent film-objects.

—Dziga Vertov, "Provisional Instructions to Kino-Eye Groups,” $1926^{1}$

[It is urgent] to take over the medium with a cost so low it could be within the reach of many individuals, like paper and ink, paints; film and lenses should have been brought home like sewing machines...

—Cesare Zavattini, "Wonder," $1940^{2}$

Imperfect cinema cannot lose sight of the fact that its essential goal as a new poetic is to disappear. ... Art will not disappear into nothingness: it will disappear into everything.

-Julio García Espinosa, "For an Imperfect Cinema," 19673

These quotations-from the celebrated Soviet pioneer of avant-garde documentary; the Italian writer and filmmaker most commonly associated with his contributions to Neorealist cinema; and one of the leaders of the Cuban Institute of Film Art and Industry, respectively-come from filmmakers from

* Many thanks to Georgio Bertellini, Luca Caminati, Roger Gathman, Anne Kern, Ilya Kliger, and Joshua Malitsky for their helpful suggestions on earlier drafts of this essay, and Malcolm Turvey for his editorial feedback.

1. Dziga Vertov, Kino-Eye: The Writings of Dziga Vertov, ed. Annette Michelson, trans. Kevin O'Brien (Berkeley: University of California, 1984), pp. 70-71.

2. "I sogni migliori," Cinema 92 (1940), translated in English as "Wonders," in Zavattini: Sequences from a Cinematic Life, trans. William Weaver (Englewood Cliffs, N.J.: Prentice-Hall), p. 2.

3. Julio García Espinosa, "Por un cine imperfecto," Cine Cubano 42-44 (1967); trans. as "For an Imperfect Cinema," in New Latin American Cinema, vol. 1, ed. Michael T. Martin (Detroit: Wayne State University, 1997), p. 82. 
different generations and continents. Yet they articulate a similar utopian call to democratize cinema by abolishing individual film authorship and dismantling film's status as art, thereby opening cinematic production to the masses and in the process liberating humankind. Such a call is particularly striking not only because it issues from well-established auteurs but because it emerges precisely at the moment of the institutionalization of cinema both as practice and as discourse in the Soviet Union, Italy, and Cuba. It raises two sets of questions. First, what does this dissolution of authorship and art promise as it emerges in these different contexts, and what contradictions, if any, does it point to in their respective historical and cultural moments? Second, what are the historical links, both artistic and theoretical, between these moments? While it is commonplace to point to the importance of the historical avant-gardes-and early Soviet film, in particular-for the development of theories and practices of Third Cinema (to which Cuban cinema of the 1960s belongs), the exact nature of the connection remains unexplored.

This essay traces one strand of the global network of leftist artists and their debates as they migrated from one cultural and regional context to another. It is this migration of motifs, interpretations, agents, and institutions that ultimately connects the initial moment of political modernism in cinema-the 1920 s - to its critical and artistic revival in the $1960 \mathrm{~s}$, and that creates a system of reverberations between the respective theoretical and artistic approaches of these periods. This particular history begins in 1920s Italy.

Soviet-Italian Cinematic Exchanges

Italian film culture of the 1920s and 1930s developed in active dialogue with contemporary film theory and practice, a dialogue that both reflected and subverted the Fascist ethos of the time. Soviet cinema occupied a privileged place in Italian film criticism, and dialogue between the two was extensive during these decades, both on the Fascist state-sponsored level and among leftist cultural and artistic figures.

As Ruth Ben-Ghiat explores in detail in her work, the Italian attitude to Soviet Russia in the 1920s and '30s synthesized certain Fascist preoccupations and positions. While the Fascists admired Soviet cinema as a model of the alternative development of one of modernity's key industries, they did not intend to give any weight to the Soviet-materialist analysis of film. ${ }^{4}$ Yet the interests of the Fascist state in the economic organization of the Soviet film industry and the use of film as a didactic instrument meant there were intersections with certain features of the materialist approach to filmmaking. Moreover, the theoretical polemics that preoccupied scholars, critics, and producers of Soviet cinema were similar to those discussed in the Italian artistic scene among leftist fac-

4. Ruth Ben-Ghiat, Fascist Modernities: Italy, 1922-1945 (Berkeley: University of California, 2001). 
tions of the late Futurist movement and the proponents of Gramsci's Proletarian Culture group. These polemics centered on the questions of what form a revolutionary art should take and what "realism" meant in the context of progressive art. ${ }^{5}$ Such debates came to an abrupt end after the Fascist clampdown on artistic pluralism, but many of their themes migrated into film criticism and pedagogy, in particular under the auspices of the Centro Sperimentale di Cinematografia, and helped shape the conceptual structure of Italian film discourse in the immediate pre-and postwar years.

In the 1920s and early '30s, Mussolini's government encouraged Italians to look at Soviet Russia as a state with which their own new order had many affinities-albeit as fascism's "enemy twin."6 The press of the time exploited the various similarities between the Soviet and Italian situation, and Lenin's dictum "Cinema is the most important of the arts" was rephrased by Mussolini as "Cinema is the strongest weapon!" Given that the legitimacy of both countries was grounded in an appeal to the masses, it was logical that the new mass art would become the preferred channel of Italian-Soviet détente. In addition, Soviet film theory and practice became a special reference point in critical debates about cinema's medium-specific properties among certain Italian artists engaged in the broader debates of European film circles. ${ }^{7}$ The most advanced at using the state's power to implement the development of cinema as a didactic tool, Soviet Russia seems to have been an inevitable model for the Italian film industry. Film schools already existed in Germany and France, and isolated film courses were being taught in U.S. universities. But only Soviet cinematic education was implemented on a truly broad scale as part of a larger humanities framework, in which it was integrated not only with craft training and film appreciation but also with the study of aesthetics at large, while at the same time remaining a distinct scholarly discipline.

A number of journals over these years featured regular pieces on Soviet cinema that celebrated Soviet montage for demonstrating the essential, distinguishing capability of cinema. Alessandro Blasetti's Cinematografo, which led the battle to define cinema as an art, published numerous articles debating whether Soviet film should be used as an appropriate model for reenergizing the laggard Italian film industry. ${ }^{8}$ Starting in the late 1920 s, Italian journals-both those specifically dedi-

5. For a detailed account of this, see Umberto Carpi, Bolscevico immaginista: Comunismo e avanguardie artistiche nell'Italia degli anni venti (Naples: Liguori editore, 1981), and Giovanni Lista, Arte e politica : il futurismo di sinistra in Italia (Milano: Multhipla, 1980).

6. Ben-Ghiat, Fascist Modernities, p. 38.

7. For a larger European context for this dynamic, see Malte Hagener, Moving Forward, Looking Back: The European Avant-garde and the Invention of the Film Culture 1919-1939 (Amsterdam: Amsterdam University, 2007).

8. See in particular Vinicio Paladini's accounts of his visit to the Soviet film studios in 1927, and the debate started by Libero Solaroli's article "Il Cinema Italiano deve imitare quello Russo," in Cinematografo 5 (March 1929), followed by a serious of articles "Cenni sulla cinematografia russa" by Mario da Silva and responses to it in Cinematografo 3 (March 1930) and "Ancora sulla cinematografia russa," Cinematografo 7 (July 1930). 
cated to cinema, such as Cinemalia, Lo Schermo, Cinematografo, and Lo spettacolo d'Italia, as well as literary and cultural journals such as La fiera letteraria, L'Italia litteraria, and Occidente-regularly featured articles and reviews of contemporary Soviet film. ${ }^{9}$ By the early 1930s, translations of Soviet film theorists started to appear in these and other venues as well. ${ }^{10}$

These and other sites for the transmission and translation of Soviet cinema and film theory almost without exception occupied an institutional gray area that, while fully aligned with the Italian Fascist state, nonetheless enjoyed a semiautonomous status and effectively engaged in-and sometimes succeeded in creating - a film culture as a public sphere. These were cine-clubs and GUFs (university Fascist youth clubs that screened and produced films); educational and research centers such as the International Institute of Educational Cinematography (L'Instituto Internazionale di Cinema Educativo or L'IICE); the National Film School (to become Centro Sperimentale di Cinematografia); the journals associated with these institutions: Revue internationale du cinéma educateur, Intercine, Cinema, and Bianco e nero; and, to some degree, even the Venice Film Festival (founded by the head of L'IICE, Luciano De Feo). All of these institutions were interconnected, and all remained in close contact with Soviet cinema and promoted it in their practices. L'IICE, for example, was founded in 1928 under the auspices of the League of Nations and aimed to promote educational documentaries and serve as a major forum for international cinematic discourse. ${ }^{11}$ During its brief existence, the Institute organized several film and photography exhibits, including the Venice Film Festival; sponsored a monthly journal published in five languages between 1929 and 1934; carried out a series of massive international surveys on film and education; and even attempted to undertake the creation of a complete encyclopedia of cinematography. Rudolf Arnheim, a member of L'IICE, began writing his seminal Film as Art as part of this project. ${ }^{12}$ Such figures as László Maholy-Nagy and Germaine Dulac were also involved with the League's institute. ${ }^{13}$ At the same time, key figures in L'IICE occupied governmental positions in Mussolini's state-run film propaganda units.

9. It is worth noting, however, that most of the knowledge of Soviet cinema in Italy at the time was in fact secondhand, stemming from the critical appraisals in Germany and France, where Soviet films were shown, largely thanks to the efforts of Léon Moussinac and his Ciné-Club de France.

10. For a different articulation of this argument, see Masha Salazkina, "Soviet Film Theory in 1930s Italy: Towards a New Genealogy of Neorealism," in Global Neorealism: The Transnational History of a Film Style, ed. Robert Sklar and Saverio Giovacchini (Jackson: University of Mississippi, 2011).

11. See Christel Taillibert, L'Institut international du cinématographe éducatif (Paris: L'Harmattan, 1999); Zoe Druick, “'Reaching the Multimillions': Liberal Internationalism and the Establishment of Documentary Film," in Inventing Film Studies, ed. L. Grievson and H. Wasson (Durham: Duke University, 2008), pp. 67-92; and Zoe Druick, "The International Educational Cinematograph Institute, Reactionary Modernism, and the Formation of Film Studies," Revue canadienne d'études cinématographiques 16 , no. 1 , pp. 80-97.

12. For more on Arnheim's role, see Jürgen Wilke, "Cinematography as a Medium of Communication: The Promotion of Research by the League of Nations and the Role of Rudolf Arnheim," European Journal of Communication 6, no. 3 (1991), pp. 337-53.

13. Druick, "The International Educational Cinematograph Institute," p. 88. 
In traditional scholarship, L'IICE had been seen as a liberal alternative to communist-oriented cultural cosmopolitanism (i.e., communist internationalism), however tainted by its associations with the Fascist government. Recent research, however, shows that L'IICE planned to involve Soviet film organizations directly. As head of the Institute, De Feo tirelessly searched for ways to include Soviet organizations in its pedagogy, its encyclopedia project, and its congresses. For over a decade, he tried to transplant the Soviet model to Italy by creating a modus vivendi between L'IICE and Soviet film institutions. Thanks to his efforts, a great deal of printed material from the Soviet Union was published in the journals associated with the Institute, Revue internationale du cinéma educateur (RICE), Intercine, and even Cinema, which at its inception in 1936 was also affiliated with the Institute. Of particular interest to De Feo, as he states in the correspondence, were "cultural, scientific, and educational films, especially films dealing with the rationalization of labor and agriculture." 14 Another area of interest was the Soviet development of sound technology: Alexander Shorin, one of the two Soviet scientists conducting research on sound systems, sent materials for publication in Intercine and for inclusion in the Encyclopedia project. ${ }^{15}$ As a result of his official visit to the Soviet Union in 1932, De Feo managed to arrange for Soviet participation in the first two Venice Film Festivals. ${ }^{16}$ In the end, however, the political obstacles were insurmountable and L'IICE failed to involve the Soviet film industry and its film-education institutions in its world congress on educational cinema or the encyclopedia of the history of cinema.

L'IICE's engagement with the Soviet models of didactic film-making was concentrated, but it was of rather limited consequence to the broader Italian film culture. A much more important development in the interwar years was the founding in Rome of the National Film School (Scuola Nazionale di Cinematografia), which eventually became known as Centro Sperimentale and was inspired by Soviet film educational structures. When the government categorically rejected the Soviet embassy's proposal to give Soviet films a wider distribution, it forced those who wanted to show and discuss Soviet cinema into the noncommercial venues that were springing up to host screenings and discussions of film. ${ }^{17}$ Ironically, Soviet cinema thus became the cornerstone of cinematic education in 1930s Italy, primarily through the work of the Centro Sperimentale.

14. This correspondence is in the State Archive of Russian History, GARF f. 5283 op.7, d. 543.

15. GARF f. 5283 op. 7, d. 664 .

16. For details, see Stefano Pisu, “L'Urss e l'Occidente: L’Unione Sovietica alla Mostra del cinema di Venezia negli anni Trenta," Bianco e nero 567 (May-August 2010), pp. 93-109, and Salazkina, "Soviet-Italian Cinematic Exchanges, 1920s-1950s, from Early Soviet Film Theory to Neorealism," pp. 37-51.

17. Ben-Ghiat, Fascist Modernities, p. 78. For more on the importance of the cine-clubs alongside the activities of the Centro Sperimentale for emergent Neorealist filmmakers, see the interview with Carlo Lizzanin in Vito Zagarrio, Cinema e fascismo: Filmi, modeli, immaginarii (Venezia: Marsilio, 2004), pp. 266-67. 
The Centro's role in the history of Italian cinema is well known. Less well known but equally important is its function as a major site of international cultural dialogue both in the pre- and the post-WWII periods. The initial idea for a national Italian film school came from Anton Giulio Bragaglia, one of the key figures of Italian Futurism and someone with long-standing ties to the Russian and Soviet avant-garde (in particular to Vsevolod Meyerhold). In 1930, when Bragaglia proposed establishing a school that would bring together artistic experimentation and academic research, he referred to the School of Screen Arts in Leningrad and to Trauberg and Kuleshov's experimental studios, as well as to the Moscow Institute of Cinematography (GIK, later VGIK) to support his idea. Bragaglia's proposal to the state agency dealing with mass media in Fascist Italy (Corporazione dello specttacolo) drew on German and Russian models and was centered on actor training, teaching, and practice, with the teaching to be based on 1) theoretical culture; 2) experimental application of scholarly ideas; and 3) practical artistic work. ${ }^{18}$ The school opened in Rome in 1932, and two years later was reorganized as the Centro Sperimentale di Cinematografia, in a move to give the state more control over film. Luigi Chiarini, who at that point was best known as a literary critic and follower of Giovanni Gentile's neoCrocean Fascist-idealist ideology, was appointed as the Head of the Centro. Chiarini brought along his friend Umberto Barbaro, and the two of them would be largely responsible for the Centro's program and for the film journal Bianco e nero, founded in 1937 under its auspices.

In what amounted to an institutional manifesto, Chiarini announced in 1934 that the theoretical platform for the Centro would serve as an instrument for creating a new realist cinema pointing explicitly to the "new realism" implicit in Pudovkin's use of montage. 19 The reference to Pudovkin is surprising, especially as Chiarini was an ardent supporter of neo-Croceanism, which would seem antithetical to the Soviet avant-garde. Moreover, Pudovkin's films were not in circulation in Italy at the time (except for some isolated screenings that took place at the Soviet embassy). They were not even included in the showcase of Soviet films presented at the 1932 and 1934 Venice Film Festivals. But Chiarini was involved in the publication of Barbaro's translation of Pudovkin's writings under the title Il soggetto cinematografico (1932). Translations of Pudovkin's text were collected again in 1935 under the title Film e fonofilm, which became one of the primary texts used in the curriculum at the Centro. In addition to Pudovkin's translations, Barbaro and Chiarini put together collections of film texts to be used for cinematic education at the Centro: "I problemi del film," "L'attore" e "L'arte dell'attore," which consisted in large part of

18. Ernesto G. Laura, “CSC dal fascismo allo stato democratico,” Bianco e nero 5/6 (1976), pp. 4-29.

19. Luigi Chiarini, Cinematografo (Roma, 1934). Quoted in ibid., p. 12. 
writings by Pudovkin, Eisenstein, and Balázs. ${ }^{20}$ As much if not more than Soviet films it was Soviet writing about film that proved critical to the institution's development throughout the 1930s.

\section{Umberto Barbaro}

Barbaro viewed Soviet cinema as "the starting point and as an example for the rebirth of Italian cinema." 21 His friendships and artistic collaborations with Vinicio Paladini and other leftist Futurists were key to his engagement with the Soviet avant-garde.22 From 1925 until the late 1930s, Barbaro and Paladini worked together on a number of avant-garde projects, first within the futurist framework (with Balla, and then in Bragaglia's Teatro degli Indipendienti in Rome), and then as part of Imaginismo, a new group they founded that was a peculiar fusion of Futurism, Constructivism, and Surrealism, with particular emphasis on the circus and Luna Park aesthetic. In the late 1920s, they moved steadily towards cinema and the new discourse on "realism" and "art based on reality," as filtered through the Soviet avant-garde. Paladini's small press, La Bilancia (Libra), named after the Russian symbolist group of the same name, published not only manifestos and essays by Italian avant-garde groups but also works on Soviet art, including a review of the exhibition of Soviet art at the art pavilion in Venice in 1924. ${ }^{23}$ Like Barbaro, Paladini saw the Soviet avant-garde as the model for marrying experimental techniques to a radical political program in Italy; he also produced a number of works in the style of Soviet Constructivism, often referring to himself as a "fotomonteur." His theater of "Futurist Mechanical Ballet" was emblematic of the Futurist ethos of the time

20. In advocating for cinema's social and educational use as against its commercial use, Chiarini and Barbaro were unlikely allies. Chiarini idealistically saw cinema as an expression of individual creativity and a means for the aesthetic education of the people; Barbaro viewed it as the product of collective labor that raised the consciousness of the masses about society. The GUF and the Centro were supposed to create a new generation of filmmakers by providing institutional spaces for the emerging social and aesthetic discourse on film within the limits of the Fascist project. Yet the institution's emphasis on international film and dialogue unintentionally undermined the nationalist aesthetic as officially conceived.

21. Quoted in Gian Piero Brunetta, Storia del cinema italiano, vol. 2 (Rome: Edizioni Riuniti, 1993), p. 170. Translations mine.

22. By the early 1920s, Paladini, whose mother was born in Moscow and raised in Rome, had an established place in the Italian cultural scene promoting the work of the Soviet avant-garde, in particular the Constructivists and Supremacists. He was on good terms with Gramsci's Ordine Nuovo circle in Turin, where he participated in the 1922 Futurist show and contributed articles to Avanguardia, the official organ of the Federation of Young Socialists, a forum for debate on progressive culture and the role of art in socialism in the early 1920s. In 1923-24, together with Barbaro, Paladini published in the near-anarchist (but sympathetic to the Soviet Union) journal Fede!, where he continued to develop his ideas about the revolutionary role of the intellectual and artist in society. See Giovanni Lista, Dal futurismo all'immaginismo: Vinicio Paladini (Bologna: Edizioni del Cavaliere Azzurro, 1988), p. 22.

23. Vinicio Paladini, Arte nella Russia dei Soviets; il padiglione dell'U.R.S.S. a Venezia (Roma: Edizioni de "La Bilancia," 1925). 
and explicit about the machine as both a vehicle and a metaphor for the communist revolution, one that mediated between the artist and the industrial production process. Contrary to the aesthetic protest against the dehumanizing effects of industrialization, industrial production itself was here turned into art in the service of modernism understood not in opposition to realism but as a reaction against bourgeois commodity culture with its total separation of production and consumption. ${ }^{24}$ In 1927, Paladini entered a contest for set design organized by Blasetti's famous journal Cinematografo with sketches clearly modeled on Alexander Exter's work (which he praised in his review of the Russian pavilion), and the following year, reflecting the growing interest he and Barbaro shared in cinema, Paladini made a trip to the Soviet Union where, among other things, he explored the intersections between Constructivism and cinema, and the Soviet movement of factography. Upon his return to Rome, he published a series of texts consisting of an account of his trip and reflections inspired by it. 25 These, and a series of other writings from 1928 and 1929 by Paladini and Barbaro refer to Alexei Gan's recent essays on Constructivism in cinema and works by Pudovkin and Vertov, thereby testifying to the temporary alignment of Italian leftist Futurism with the Soviet Constructivist and Productivist ethos. ${ }^{26}$ Paladini also tried to establish regular correspondence with Vertov, whom he had apparently met during his trip to the U.S.S.R., in order to arrange for Vertov's writings to be translated into Italian (although there is no record of a response by Vertov to such eager letters). 27 Paladini continued to work with Barbaro on various film projects, both theoretical and realized, until the late 1930s, in particular on the set of Barbaro's 1937 film L'ultima nemica. ${ }^{28}$

It is thus in the context of Barbaro and Paladini's shared artistic production that Barbaro's engagement with Soviet film theory and its incorporation into the new Italian realist aesthetic is best understood. Even though the key moment in Barbaro's theoretical and pedagogical trajectory remains his discovery of Pudovkin's writings and his formulations of realism, this moment should be seen as a continuation of the discursive and artistic field of Futurism and Constructivism. Throughout his life, Barbaro stressed in his critical writings that film's great interest for him lay in its possibility to fuse the aesthetic and the political, its potential to forge a "critical consciousness." This position is perhaps best expressed in the introduction to his published translation of Béla Balázs. As

24. For an articulation of this aspect of modernist art, see Walter Adamson, Embattled Avant-Gardes: Modernism's Resistance to Commodity Culture in Europe (Berkeley: University of California, 2007).

25. Vinicio Paladini, "Cinematografo e teatri in Russia sovietica," Cinemalia 2, no. 8 (1928), pp. 23-24.

26. See Vinicio Paladini, "Estetica cinematografica," Cinemalia 2, no. 19 (1928), p. 35, and "Cinematografo dal Vero," Cinema-teatro (September 15, 1928).

27. RGALI f. 2091, op. 2, d. 351.

28. Unlike Barbaro, however, Paladini was unable ultimately to find a niche for himself in Fascist Italy, despite Barbaro's (failed) attempts to get him involved in the Centro; by the late 1930s he had chosen to emigrate to the U.S., where his career in architecture and set design effectively ended. 
Gian Piero Brunetta argues, Barbaro’s description of Balázs could equally be applied to the translator himself:

Work for him was an unbreakable union of theoretical and practical activity, not merely a way to understand and explain the world but a contribution to its transformation. [Work] was a free and full expression and expansion of a man solidly tied to other people with the same orientation ... an exemplary life of a man both free and social, i.e., fully human. ${ }^{29}$

With this goal in mind, Barbaro took up Pudovkin's writings as a weapon for implicitly opposing the Crocean idealist model of art (which was an officially accepted aesthetic position in Fascist Italy best exemplified by the work of Barbaro's colleague Chiarini). Positioning art as the individual expression of a higher order, a realm of beauty and lyrical expression separated from the everyday world, this stance denies cinema's revolutionary potential and relegates the film theorist to the task of writing appreciations and evaluations-precisely the role of the critic in mass media, whose place as an arbiter was prescribed by the system of distribution and publicity of commercial studio film. ${ }^{30}$

What Barbaro found in Pudovkin above all others was a means of understanding an object that demystified the individualistic notion of the auteur and raised questions about the institutional setting in which art was produced, distributed, exhibited, and received-without undermining the organizational role played by the film director. ${ }^{31}$ As Pudovkin states in one of his earliest essays:

A film factory has all the characteristics of industrial production. The leading engineer can do nothing without his experts and workers. Their mutual efforts will come to nothing if each worker were to limit himself to the mechanical execution of his narrow function. Collective work is what makes every part of the work a living and organic part of the larger goal/task. The nature of filmmaking is such that the more people take a direct and organic involvement, and the more varied their involvement in the work - the better is the final product of this process - the film. ${ }^{32}$

While far from Vertov's (and later, Zavattini's) call for the absolute democratization of the medium, Pudovkin's analysis points to the potential alienation of labor involved in the very process of filmmaking, and underscores both its collec-

29. Gian Piero Brunetta, Intellettuali, cinema e propaganda tra le due guerre (Bologna: Patron, 1972), p. 149 .

30. It is ironic, however, that Barbaro himself, especially in the postwar period, became just that kind of critic, evaluating the films based on his own very narrow ideological criteria of "critical realism" against the "excesses of formalism" following the Zhdanovite line of the Communist Party.

31. Unlike Eisenstein, whose theoretical writings are primarily concerned with form and rarely engage with the conditions of production or questions of collectivism.

32. Vsevolod Pudovkin, "Kollektivizm-baza kinoraboty" (Collectivism is the foundation of cinematic work), in Sobranie sochinenii v trekh tomakh, vol. 1 (Moscow: Iskusstvo, 1974), p. 129. Translations mine. 
tive nature and the organizational role of the author-director (so typical of the Constructivist ethos).

It was, however, Pudovkin's insistence on "realism" that resonated most within Italian film culture of the early 1930s. In Barbaro's writings, realismdefined not so much as an artistic style as the artwork's relationship to its material and social context-becomes the central concept. Such a discourse had its origins as part of the larger avant-garde project of reawakening the materiality of the world through art, so that art could transform the material world. In Pudovkin's writings from the 1920s there are resonances of the Russian-formalist slogan of "making stone stony again," where ostranenie is understood as a set of formal techniques and as a means by which an individual could reconnect with the world around her through art. Similarly, Soviet avant-garde artists' emphasis on the notion of faktura as both a heightened sense of materiality and, in Maria Gough's words, an "index of material presence" was integral to the larger utopian project of overcoming the gap between art and reality. ${ }^{33}$ For Soviet cinema of the 1920s this meant an emphasis on textures and film's own photographic qualities, combined with an understanding of montage as conscious "engineering" of the filmic material, thus placing the material composition of film under the same strict rules for organizing labor as the rest of the social and political reality. Cinema-despite the "immateriality" intrinsic to its mechanism of projecting upon the two-dimensional plane of the screen an image of three-dimensional space-contributed to the larger project of revolutionizing the relationship between the human subjects and the material world around them by creating a new sensory regime for the spectator. ${ }^{34}$ The ultimate goal of this revolution was, of course, not merely aesthetic but political.

As Barbaro would elaborate it in his later writings,

art arises from reality and tries to know it and transform it . . . so that an old definition of art may begin to steal into one's mind: the transfiguration of reality. Thus, from direct energy for the satisfaction of an immediate and practical need, the imagination has become more and more intricately conditioned by the forms of social and individual life, transforming itself into energy that becomes conscious of the world in its particular way (through images) and at the same time becomes conscious of its own manifestations and work, of the value of the product and its effects and weight. ${ }^{35}$

At the same time, Pudovkin's writings reflect the general turn in leftist artistic

33. Maria Gough, The Artist as Producer: Russian Constructivism in Revolution (Berkeley: University of California, 2005), pp. 11-12.

34. On the role that set design played in this project, see Emma Widdis, "Faktura: Depth and Surface in Early Soviet Set Design," Studies in Russian and Soviet Cinema 3, no. 2 (2009), pp. 5-32.

35. Umberto Barbaro, "Materialism and Art," in Marxism Eं Art: Writing in Aesthetics and Criticism, ed. Berel Lang and Forrest Williams (New York: Longman, 1972), p. 161. 
circles toward figuration and narrative, and away from the earlier formalist emphasis on the representation of social and economic processes through cinematic style (exemplified by Vertov and Eisenstein's work of the late 1920s, as well as, to some extent, Pudovkin's own). While this shift is usually attributed to the onset of Socialist Realism as the official Stalinist line, outside the strictly Soviet context these developments had larger resonances and helped give rise to a variety of "critical realisms" in the arts of the 1930s and '40s. ${ }^{36}$ Despite the traditionalism of Pudovkin's position as compared to Vertov's, for example, his theoretical work of the 1920s must be understood as successfully mediating avant-garde impulses and the emerging aesthetic rhetoric of realism, not unlike the contemporary factographic discourses. 37 The goal of Pudovkin's cinema, as Tret'iakov underscored in his writings, was to create new sets of relations between the sign and the external world, thereby reawakening the materiality of the world and enabling access to the viewer's consciousness and its transformation. At the same time, this cinematic realism employed fixed representational "types," thus continuing the positivist-realist project of the nineteenth century arguably built into the very apparatus of cinema, the photographic representation. ${ }^{38}$ Thus, on the one hand, Pudovkin's realism was compatible with the Italian literary legacy that Barbaro and others at the Centro were tracing (such as verismo and other "indigenous" literary forms of realism, which also arose under conditions of social upheaval). ${ }^{9}$ On the other, Pudovkin's insistence on the primacy of what he calls "expressive visual material" (vyrazitel'nyi plasticheskii material) as a point of orientation for screen-writing participates in the debates on cinema's medium-specificity found in Arnheim's and Balázs's theories, which were also in circulation at the Centro. His insistence on the importance of a script underscored the collective nature of filmmaking, an element for organizing a collectivity through a shared artistic task:

It is not a lone director who is called upon to resolve the creative task [of filmmaking]. Only a community united by a shared idea and a unified understanding of a goal (zadachi), creative and controlling itself (sam sebya kontroliruyuschii), can do such work [of real filmmaking].40

36. For a contemporary position emphasizing the Stalinist vision behind Neorealism, see James T. Farrel, "The Problem of Public Sensibility: A Review of The Open City," October 128 (Spring 2009), pp. 69-84.

37. Pudovkin, in turn, is used by Sergei Tret'iakov to illustrate factographic principles. See Sergei Tret'iakov, "Our Cinema," quoted in Devin Fore, "The Operative Word in Soviet Factography," October 118 (Fall 2006), pp. 104-5.

38. For a detailed elaboration of this, see Nancy Armstrong, Fiction in the Age of Photography: The Legacy of British Realism (Cambridge: Harvard University, 1999).

39. For more on the literary origins of the Neorealist debates in Fascist Italy, see Ben-Ghiat, Fascist Modernities, pp. 46-61, and Luca Caminati, "The Role of Documentary Film in the Formation of the Neorealist Cinema," in Global Neorealism, p. 56.

40. Vsevolod Pudovkin, "O scenarnoi forme," Sobranie sochinenii v trekh tomax, t.1, (1974), p. 47. Translation mine. 
This vision of artistic creation as creative labor must have seemed to Barbaro to be just what he was searching for as he constructed an ideology for the new Italian cinema that did not sever its connection with realism but did attack the idealist, passive form of it. It was "technical" enough to account for the medium-specificity of cinema, emphasizing montage, and it foregrounded film's popular nature (both in its creation and its effect), which made film a distinctive form of industrial production and consumption, both a genuinely anti-elitist and thoroughly modern practice. But, in the final instance, it redeemed the figure of the artist as a critical organizing force.

For Barbaro, then, the natural consequence of this understanding of realism was a transformative rather than mimetic conception of cinema: art "is not limited to making an interpretation of the world, but intends to actively transform reality." 41 This quotation recapitulates almost exactly the Soviet factographic notion of realism in which "[factography] had nothing to do with the naïve and lying verisimilitude of bourgeois realism's aesthetics of resemblance. Rather its interventionist, operative aesthetic called upon the producer not simply to depict life, but to create it anew in the process." 42 The criticism of Neorealism as "politically ineffective" has caused many to lose sight of this connection; however, it was Barbaro's politicized discussions of Neorealism as realizing the transformative potential of cinema-rather than, say, Bazin's description of Neorealism as a film movement with specific formal and stylistic characteristics-that strongly influenced the global network of theorists and practitioners of political modernism of the 1950s and '60s (including Gillo Pontecorvo, theorists and cineasts of Cinema Novo in Brazil, and of Cuban Imperfect Cinema). Unlike most of these subsequent political filmmakers and theorists, however, Barbaro preferred Pudovkin's theories of montage to Eisenstein's, which he considered too idealist in their philosophical conception. Pudovkin was a greater realist for Barbaro because of his more "pragmatic" attitude towards filmmaking as a collective activity, which required a different kind of organization of production and placed the issue of aesthetic labor at the center of the discussion. Another aspect of Pudovkin's "pragmatism" was the accessibility of his writings and their concern with solving practical filmmaking problems, which made them easy to enlist in the pedagogical critical practice the Centro embraced in its fusion of theory and practice.

The discourse on political cinema in Italy was able to be so strongly shaped by the Soviet one because the two shared a vernacular: Marxists could thus argue against Fascism while using Fascist language. Barbaro's anti-idealist polemic, which employed the Fascist terminology of realism, was in fact an attack on Gentile and the Fascist cultural Establishment. Chiarini opposed the Fascist promotion of

41. Pudovkin, V.I. Pudvkin, Il soggetto cinematografico (Eizioni d'Italia: Roma, 1932), quoted in Gian Piero Brunetta, Umberto Barbaro e l'idea di Neorealismo (Liviana, 1969), p. 28.

42. Sergei Tret'iakov, Feld-Herren: der Kampf um eine Kollektiv-Wirtschaft (Berlin: Malik-Verlag, 1931), p. 23, quoted in Fore, "The Operative Word in Soviet Factography," p. 101. For more on the relationship between factography and cinematic realism, see Joshua Malitsky, "Ideologies in Fact: Still and MovingImage Documentary in the Soviet Union, 1927-1932," Iournal of Linquistic Anthropology 20, no. 2 (Fall 2010), pp. 352-71. 
entertainment cinema by campaigning for educational film. The Italian state's efforts to organize noncommercial sites of exhibition in fact gave birth to a public sphere that was neither simply an extension of the state nor subject to direct commercial pressure. Thus, the dialogue surrounding cinema revolved around a set of issues with both a Fascist and a hidden materialist agenda, principally the industrial organization of cinema as an educational tool and the role of the state as a guarantor of noncommercial media. The terms of this debate remained the same, while emphasis on one or another of these issues depended on the divergent and often contradictory and competing interests of elements within the larger film culture, be it the state, organizations, critics, or the filmmakers themselves. These last, in fact, in the GUF and Centro, were never clearly distinguished from the producer, critic, or institutional functionary. Barbaro's translations and his critical writings, as well as his pedagogical and editorial work, played an important role in shaping a particularly fruitful-if also highly polemical-cultural space for debate about the role of cinema. Yet while the importance of Italian Neorealism for world cinema has become a staple of film history, the development of the discourse on cinema in Italy has not been fully acknowledged by film scholars.

Two other figures in the Italian cultural scene played key roles in transmitting early Soviet film theory to Latin American critics: Guido Aristarco and Cesare Zavattini. Aristarco's publication in 1950 of a collection of texts on film theory, followed the next year by his History of Film Theories, marked a major moment in the institutionalization of the discourse on film theory. 43 Aristarco's volumes (which included and discussed the writings of, among others, Eisenstein, Pudovkin, and Barbaro) were immediately translated into Spanish and Portuguese and became an essential reference point for the postwar generation of filmmakers, and his editorial activities for the journal Cinema Nuovo created an important bridge between the prewar Marxist film discourse and the theoretical apparatus of Latin American "Third Cinemas." The reports on the development of revolutionary cinemas and the interviews (with practitioners of New Cinema in Latin America and important figures in Euro-American film culture such as Siegfried Kracauer) that he published in Cinema Nuovo were an important source of information for a growing global network of leftist artists and intellectuals. While Aristarco's postwar ideological stance, largely influenced by Gramsci and Lukàcs, was often directed against Barbaro's more orthodox Marxist-Stalinist orientation, his selection of texts was remarkably consistent with Barbaro's prewar curriculum at the Centro.

Zavattini likewise continued the dialogue between Soviet film theorists and artists of the 1920s and the new Italian film culture. Zavattini, who is still best known as a screenwriter for many of the most famous Neorealist films of the 1930s-50s, was a prolific and talented critic (as well as a writer and artist), whose intellectual and artistic development was shaped by his literary involvement in the 1920s Italian avant-garde culture in his native Parma. His theoretical and political

43. Guido Aristarco, L'arte del film: Antologia storico-critica (Milan: Bompiani, 1950); and Guido Aristarco, Storia delle teoriche del film (Turin: Einaudi, 1951). 
writings centered on the relationship between the institution of cinema and social and political reality, and his artistic work reflected a political commitment to redefining the relationship between film production and exhibition through a more direct engagement with spectators. As Giorgio Bertellini notes in his recent work on Zavattini,

In 1931, in one of his first visionary articles about cinema entitled "La macchina del 2.000" (The Machine of the Year 2000), he envisioned a much more democratic mode of film circulation capable of bypassing the constraints of traditional exhibition circuits. In the year 2000, he argued, the filmmaking process will be so simple that, in an obvious comparison with book distribution, films will be printed and will become "viewable and hearable from home." The idea of disposing of powerful mediatorsexhibitors first, but soon also producers and distributors-would remain a refrain of Zavattini's utopian ideas about cinema. Throughout his successful, but also often for him disappointing, participation in the neorealist project, his ideas about cinema translated into the imagination of unconventional filmmaking and exhibition practices. ${ }^{4}$

While Zavattini's conceptual approach had a distinctly phenomenological dimension (compatible with the postwar critical articulations of realism, such as Bazin's), his commitment to experimental forms of production and exhibition allowed for a close fit with the interests of the Latin American filmmakers and critics who were seeking to create a radical cinematic culture. Like Aristarco, Zavattini was a consistent interlocutor for the emerging critics and filmmakers of the New Latin American cinemas and an active participant in the festival circuits promoting in particular the development of the Cuban film industry and film-educational structures.

Thus, the crucial encounter of Latin American filmmakers and critics was not only with the Italian Neorealist cinema in its reified common-usage sense of "documentation of social reality," as it is often suggested in film historical narratives, but rather with a particular development of Italian cinematic culture, personified by Barbaro, Aristarco, and Zavattini. These figures acted as cultural agents of translation among Soviet, Italian, and Cuban models of film cultures in their critical, institutional, and artistic forms. Their emphasis on non-commodified forms of art should be seen as addressing the possibility-indeed, the necessity-for the creation of a public sphere through film culture. Thus it should not be surprising that their concepts continued to reemerge with particular force in authoritarian states where such a public sphere was threatened. Ironically, the close proximity of cinema to state projects aiming to modernize the population through strict regulations lead to the creation of the apparatus capable of radical reimagining of cinema as an emancipatory mechanism.

44. Cesare Zavattini, "La macchina del 2.000," Cinema Illustrazione (February 4, 1931), as quoted in Giorgio Bertellini, "Cesare Zavattini and the Avant-garde Tain of the Neorealist Mirror," unpublished manuscript. I thank the author for sharing this work-in-progress. 
These political and aesthetic issues came into sharp relief in postrevolutionary Cuba, where the project of building a new cinematic culture was given the highest priority by the state. In the first decade of its existence, the Cuban Institute of Film Art and Industry (ICAIC) created a sharply demarcated, ideologically determined hierarchy within Cuban film culture; at the same time, it provided a vibrant and cosmopolitan space for artistic and theoretical experimentation for those who were on the inside. Its key foundational figures were in constant dialogue with other Latin American and European leftist artists and intellectuals, and consciously reflected on their broad-based knowledge of cinema, Marxist theory, and the political realities of film institutions. While their engagement with contemporary French, British, and U.S. intellectual figures was clearly marked by the concerns and structures of the New Left, and they were united in their rejection of the conservative legacies of the older communist parties (a process that was also taking place in Italy at the time), much of the ICAIC's practice involved responding to problems formulated by earlier generations of radical filmmakers and theorists. Many of these were assimilated through dialogue with Italian film culture, especially the Centro and its theoretical legacies (including Barbaro's work); through regular contacts with Aristarco's journal Cinema Nuovo and Zavattini; as well as through Cuban participation in a number of independent film festivals in Italy in the course of the 1960s.

As a sign of both the influence of the Centro/VGIK model of centralizing film culture and of how much the new Communist regime valued film, one of the first acts of the revolutionary government, in March 1959, was to establish the Instituto Cubano de Arte e Industria Cinematografica (ICAIC). ${ }^{45}$ Law 169, which gave the ICAIC control of film production and distribution, the studios and all other infrastructure, and the training of filmmakers and technicians, explained the government's reasoning: "Because film is an art. Because cinema constitutes, due to its characteristics, an instrument of opinions that form individual and collective consciousness and can contribute to deepen and purify the revolutionary spirit and sustain its creative impulse." 46

Setting the tone for cultural polemics in Cuba throughout the 1960s, Law 169 raised issues of artistic labor, coupling industry and art in the Institute's very title. 47 It was no accident that Centro-trained film theorists and friends of Zavattini48_

45. For the most detailed account of the history of the ICAIC and the Cuban film industry, see Michael Chanan, Cuban Cinema (Minneapolis: University of Minnesota Press, 2004).

46. "Creacion del Instituto Cubano del Arte e Industria Cinematográfica (ICAIC)," in Pensamiento y Política Cultural Cubanos: T. IV, ed. Matilde del Rosario Sánchez (Havana: Editorial Pueblo y Educaion, 1987), pp. 7-10.

47. For some of the most important texts from these debates, see Polémicas culturales de los 60, ed. Graziella Pogolotti (Havana: Letras Cubanas, 2006); for a partial account in English, see Hector Amaya, Screening Cuba: Film Criticism as Political Performance During the Cold War (Chicago: University of Illinois, 2010).

48. For a correspondence between them, see Tomás Gutiérrez Alea, Titón: Volver sobre mis pasos, ed. Mirtha Ibarra (Havana: Union, 2008). 
notably Tomás Gutiérrez Alea and Julio García Espinosa (as well as Fernando Birri, who was the founder of the Documentary Film School in Santa Fe, Argentina, whose artistic stance became paradigmatic for ICAIC) - were from the beginning the creative leaders of the Institute. According to their accounts, as early as 1954, when they returned to Cuba under the influence of their experience in Italy, Julio García Espinosa and Gutiérrez Alea organized a group for the study of Marxism and culture, presumably under the umbrella of Nuestro Tiempo, the Communistaffiliated association based at the University of Havana. The association consisted of several sections, including a film division. In a lecture titled "Neorealism and Cuban Cinema" in May 1954 at a colloquium organized by Nuestro Tiempo, García Espinosa presented a peculiar synthesis of Chiarini's, Barbaro's, and Zavattini's pronouncements on Neorealism. What is striking, however, in light of García Espinosa's later theoretical writings is how closely it corresponded to Barbaro's and Pudovkin's discussions of realism. García Espinosa insisted on the necessity of artistic selection of the material (against the notion of simply "catching the reality of life on the streets"), thereby affirming the importance of the director's organizational role and echoing Pudovkin's concerns. He also stated that Neorealism's goal was "to register life itself on the basis of its most characteristic and typical traits," evoking both Pudovkin's idea of "typage" and Aristarco's Lukácsian language of social types. Throughout his writings from the period, García Espinosa repeated the familiar refrain that art "is not only about interpreting the world but about transforming it." 49 Much like Barbaro, who proposed that Soviet cinema serve as the model for the national rebirth of Italian cinema in the 1930s, García Espinosa insisted in 1954 on Neorealist cinema as a model for Cuban cinema, not through formal and stylistic imitation but as an approach to filmmaking deeply rooted in its own national and cultural traditions..$^{50}$ In terms of theoretical sophistication, this is a far cry from his 1969 call for an "Imperfect Cinema," which had more in common with Zavattini's (and Vertov's) project of radically democratizing filmmaking-but it is remarkably consistent with the theoretical stance of the Centro Sperimentale and early 1950s Italian film discourse. This was two years before the Twentieth Congress of the Communist Party of the U.S.S.R., when Khrushchev delivered his famous "secret speech" denouncing the cult of personality, which had immediate reverberations in pro-communist circles around the world. The resultant crisis of the cultural ideologies of the Communist Parties led to critical revisionism and the emergence of the New Left. The intellectual and theoretical formation of most of the key figures of the future ICAIC occurred at this intersection in the history of cultural Marxism, and it coincided with the Cuban revolution, which brought these debates into the open and announced them to be a matter of national priority.

The Castro-ite subsumption of civil society within the state structure was, during the revolution's utopian moment, a powerful political model for under-

49. Julio García Espinosa, Algo de mí (Havana: ICAIC, 2009), p. 94.

50. "El Neorealismo y el cine cubano," transcript of the speech at the Cultural Association Nuestro Tiempo on May 13, 1954, reprinted in García Espinosa, Algo de mí, pp. 163-74. 
standing the organization of filmmaking as a collective project. ${ }^{51}$ Consistent with Michael Chanan's claim that "the case of Cuban cinema suggests ... [that] the public sphere does not simply dissolve, but finds an active and vicarious surrogate on the film screen," the strand of film and critical theory that led from the Soviet Union in the 1920s to Italy in the 1930s was taken up in Cuban cinematic discourse of the 1960s and '70s, when the ICAIC created a cultural dynamic not entirely unlike that of the Centro Sperimentale during Fascism. ${ }^{52}$ In Chanan's words:

While the press and broadcasting became a site of ideological confrontation where the state would soon take direct control, cinema in Cuba came to occupy a unique cultural space as a major site of public discourse that at the same time enjoyed a de facto autonomy because of a privileged relation to the source of power and authority. 53

The critical apparatus developed within this discourse reflected a preoccupation with a materialist aesthetic that would enable the existence of a genuine civic society. ${ }^{54}$ Many of the Cuban filmmakers and critics had previously been actively involved in cine-clubs and cultural organizations in prerevolutionary Cuba. On the level of artistic practice, this is particularly evident in the development of mobile cinemas in Cuba in the 1960s, which were reminiscent of both Soviet cine-train projects of the 1930s and Zavattini's practices of cinegiornali liberi. 55 In Cuban intellectual circles, the most urgent debate of the early '60s concerned the status of the intellectual in the revolution and, consequently, what revolutionary role should be assigned to the artist. The solution arrived at by the Cuban school was to preserve the uniqueness of artistic labor and merge it with the democratic process, in as much as this was identified with the massive changes being effected by the revolution. Cuban artists and intellectuals in the 1960s were fully aware of the dangers of the institutionalization of the revolution and the routinization that had befallen Socialist Realism to the point of cliché. In fact, one of the first ICAIC-produced fiction films directed by Gutiérrez Alea was Twelve Chairs (Las Doce Sillas, 1962), an adaptation of a famous Soviet satirical novel of the 1920s to the realities of '60s Cuba. While ostensibly critiquing prerevolutionary elements, like his later film Death of a Bureaucrat (La Muerte de un burócrata, 1966), Twelve Chairs targeted not only the

51. This corresponds to the shift in the political struggle to a new, anti-institutional (rather than class-based) articulation of a revolutionary position.

52. Chanan, Cuban Cinema, p. 16.

53. Ibid, p. 19.

54. For a discussion of the reception of Italian Marxism in Cuba, see Michael Chanan, "Cuba and Civil Society, or Why Cuban Intellectuals Are Talking About Gramsci,” Nepantla 2, no. 2 (2001).

55. For a recent discussion of Cuban mobile cinemas as extension of the public sphere, see Nicholas Balaisis, "Cuba, Cinema, and the Post-Revolutionary Public Sphere," Canadian Journal of Film Studies 19, no. 2 (2010), pp. 26-42, and Tamara Falicov, "Mobile Cinemas in Cuba: The Forms and Ideology of Traveling Exhibitions," Public 40 (2010), pp. 104-8. On Zavattini's project of "free newsreels," see Mino Argentieri, "Cinegiornali liberi: Motivi di dissenso e consenso," Cinema Sessanta 9, no. 71 (1969). 
bureaucratic institutions but also their stylistic platitudes, and it included a parody of ICAIC's own newsreels. Against artistic ossification, these films erupt with the spontaneous, anarchic, and liberating energy of slapstick comedy.

Meanwhile, the theorists of the ICAIC turned to Barbaro and Zavattini because by emphasizing the notion of film as an expression of collective creativity, their theories turned the modernist debate inside out: it wasn't that the artist was exemplary, but rather that all individuals were repressed artists. True social liberation would thus advance under the slogan that everyone is an artist-and, by extension, civil society an artistic collaboration. In place of individual production, García Espinosa's notion of "Imperfect Cinema" encompassed

not only an act of social justice - the possibility for everyone to make films-but also a fact of extreme importance for artistic culture: the possibility of recovering ... the true meaning of artistic activity. Then we will be able to understand that art is one of mankind's "impartial" activities. That art is not work, and that the artist is not in the strict sense a worker.

Imperfect cinema cannot lose sight of the fact that its essential goal as a new poetic is to disappear...

Art will not disappear into nothingness: it will disappear into everything. ${ }^{56}$

In this sense, the re-conceptualization of Neorealism in Cuba proved to be exemplary by its lack of prescriptive criteria or fixed means of intervening in material reality. What these theorists realized was that Barbaro's understanding of realism and his use of Pudovkin, unlike the Socialist Realist mandated formula that he advocated in the last years of his life, do not associate specific techniques (like montage in Eisenstein's case or "kino-eye" in Vertov's) with class sensibilities; instead, they allow for a range of formal means, so long as the goal_or "thesis" in Pudovkin and Barbaro's terminology-of serving the revolution is retained. In 1960s Cuba, this approach proved capable of being reconciled with Fidel's famous slogan, "Within revolution-everything; outside revolution-nothing." Informed by Barbaro's thesis, Cuban theorists and filmmakers sought to create a cinema that did not dissolve the contradiction that remained at the heart of contemporary political cinematic debates: how to bridge the gap between art and political reality without suspending the autonomous status of art.

These artists refused to accept the capitalist relations of production, in which surplus value is translated into positional gain in the hierarchy of power

56. García Espinosa, "For an Imperfect Cinema," p. 82. 
and under which one can include existing forms of communism as being, in the end, variants of state capitalism. They refused to consider aesthetic labor as reducible to the same criteria as other labor, and thereby necessitated a completely new set of production relations that did not follow the model of capitalist organization. Moreover, their work implied that any kind of quantification of artistic output or any formulaic relation to the aesthetic product was impossible. In 1960s Cuba, such work had, of course, a very concrete political context. 57 The ability of Cuban filmmakers and theorists to articulate this position from within the Marxist aesthetic discourse (however unorthodox) allowed them to successfully reconcile-however temporarily-political pressures with a more sophisticated and clearly modernist approach to filmmaking.

This theoretical position was developed in dialogue with the Soviet avantgarde and Italian Neorealism (as well as with contemporary European and U.S. radical film collectives), and, importantly, with the debates going on in Brazil, Argentina, and Chile that flowed into meetings of the Third World Cinema Committee, among other places. ${ }^{58}$ For the historian, then, there are two dimensions that must be investigated in order to produce a panoramic picture of Cuban film in the 1960s: the diachronic plane, parts of which I have begun to uncover here, and two big synchronic fields- the "Third Cinemas," where the question of aesthetic labor is posed within the matrix of issues specific to the postcolonial experience, and a wider historical shift towards post-industrialism in Europe and the U.S. that undermined older certainties about the capitalist social order and gave rise to new political realities, theoretical frameworks, and artistic practices.

It is fair to assume, however, that the historical trajectory I have traced here came to an end sometime in the 1970s, and uncovering it now belongs to the kind of cultural archeology of modernity discussed by T. J. Clark. ${ }^{59}$ Any hope for Cuba as a space for political dissent belongs to the same aborted past. Political modernism, which served as a Franco-Anglophone counterpart to Latin America's Third and Imperfect Cinema, and, perhaps, film theory as a discourse tout court, also reached what seems to be a permanent crisis. ${ }^{60}$ The crises of labor politics and postindustrialism have altered the theorizations of artistic labor. And yet, the very condition of postindustrialism and information-era capitalism

57. As Chanan notes, unlike the Soviet film industry, which was removed from the Commissariat of Education to the Council on National Economy in 1929, Cuban filmmakers and theorists resisted any such developments. Michael Chanan, "Cinemas in Revolution: 1920 Russia, 1960s Cuba," in Understanding Film, Marxist Perspectives, ed. Mike Wayne (London: Pluto Press, 2005), p. 243.

58. Mariano Mestman, "From Algiers to Buenos Aires: The Third World Cinema Committee (1973/74) New Cinemas: Journal of Contemporary Film 1, no. 1 (2003).

59. T. J. Clark, Farewell to an Idea: Episodes from a History of Modernism (Yale University Press, 1999).

60. David N. Rodowick, The Crisis of Political Modernism: Criticism and Ideology in Contemporary Film Criticism (Berkeley: University of California Press, 1994), and D. N. Rodowick, "An Elegy for Theory," October 121 (Summer 2007), pp. 99-110. 
raises the questions of radical democratization and an alternative public sphere with new force, not only in relation to cinema but also the new media. The kind of utopian imagination manifested in the theories I have examined in this essay is currently in evidence in the debates concerning the creation of new communities and a new public sphere through the democratization of media platforms. This is why we need to revive and seek to understand older instances of this utopian imagination at work: to provide a much-needed historical perspective on current debates. 